\title{
Technical Note: Early harvest of squirreltail seed
}

\author{
PAUL S. DOESCHER
}

Author is professor, Department of Rangeland Resources, Oregon State University, Corvallis, Ore., USA 97330.

\begin{abstract}
Squirreltail (Sitanion hystrix (Nutt.J. G. Smith), a native, coolseason perennial bunchgrass of the Intermountain West has been shown to reinvade degraded rangelands invaded by exotic annual weeds. However, one limitation to mechanical seed collection of this species is the disarticulating nature of the rachis at seed maturity. The purpose of this reseach was to determine if early harvest of the inflorescence before disarticulation would result in viable seed. After anthesis, seeds were collected weekly in 1995 and about every 10 days in 1996 at a research site near Prineville, Oregon. Seeds were germinated for 21 days at a constant temperature of $20^{\circ} \mathrm{C}$. Germinable seeds were present at all collection dates from late anthesis to seed shatter in 1995, and all but early anthesis in 1996. Total germination, rate of germination and seed weight increased as seeds were collected later in the summer. Collection of squirreltail seed when a majority of seed awns have moved from a reddish to a divergent, straw colored appearance resulted in germination properties similar to fully mature seed. This occured about 1 week prior to the onset of seed head disarticulation.
\end{abstract}

Key Words: Germination, phenology, competition, restoration

Squirreltail (Sitanion hystrix (Nutt.J. G. Smith)=Eylmus elymoides (Raf.)Swezey)] is a short-lived, cool season perennial grass native to a diverse number of arid habitats in the Intermountain West. Generally considered a low-seral species, it is often observed to be one of the few native grasses capable of reestablishing on rangelands that have been invaded and dominated by alien annual species such as medusahead (Taeniatherum caput-medusae ssp. asperum (Sink.) Melderis) and cheatgrass (Bromus tectorum L.) (Hironaka and Tisdale 1963, Hironaka and Sindelar 1973, 1975). Rapid seed germination, vigorous seedling development, and the presence of a disarticulating seed head that facilitates seed dispersal by wind are characteristics promoting the establishment of this species on weed dominated sites (Hironaka and Sindelar 1973, Mack and Pyke 1984, Jones 1998).

Although squirreltail would seem an excellent species for revegetation purposes, the disarticulating nature of the rachis poses a limitation to mechanical seed collection (Young and Evans 1977).

Manuscript is submitted as Technical Paper \#11572 Oregon Agricultural Experiment Station, Oregon State University, Corvallis, Oregon, USA 97331. Thanks to Gordon Schumacher and Stacy Platt for their assistance, and to Drs. Michael Borman and Steve Sharrow for their careful review of earlier drafts of this manuscript.

Manuscript accepted 11 May 2000.

\section{Resumen}

El zacate "Squirreltail" (Sitanion hystrix Null. J.G. Smith) es una especie nativa perenne de estación fría de la región intermontana del oeste que ha sido demostrado que reinvade los pastizales degradados e invadidos con malezas anuales exóticas. Sin embargo, una limitante para la cosecha mecánica de semilla de esta especie es la naturaleza desarticulante del raquis cuando la semilla esta madura. El proposito de este estudio fue determinar si la cosecha temprana de la inflorecencia, antes de la desarticulación, producirá semilla viable. En un sitio experimental cerca de Prineville, Orergon se colecto semilla después de la antesis, la colecta se hizo semanalmente en 1995 y cada 10 días en 1996. Las semillas se germinaron durante 21 días a temperatura constante de $20^{\circ} \mathrm{C}$. En 1995 hubo semillas germinables en todas las fechas de colección, desde fines de la antesis hasta la caída de la semilla, en 1996 en todas las fechas, menos en el inicio de la antesis, también hubo semilla germinable. La germinación total, la tasa de germinación y el peso de la semilla aumento conforme las semillas se colectaron al final del verano. La colecta de semilla de "Squirreltail" cuando la mayoría de las aristas de la semillas han cambiado de rojizo a divergente y la apariencia de la paja es coloreada resulto en propiedades de germinación similares a los de semilla totalmente madura. Esto ocurrió aproximadamente 1 semana antes del inicio de la desarticulación de la inflorecencia.

The objective of this research was to determine if harvest of the inflorescence before disarticulation would result in viable seed.

\section{Materials and Methods}

\section{Seed collection and processing}

Squirreltail seeds were collected during the summers of 1995 and 1996 on a site near Prineville, Ore. (T 15S R17E Sec.18). The collection site was at an elevation of $1,140 \mathrm{~m}$ and characterized by a dominance of $<100$ year old western juniper (Juniperus occidentalis Hook.), big sagebrush (Artemisia tridentata Nutt.), low sagebrush (Artemisia arbuscula Nutt.), bluebunch wheatgrass (Agropyron spicatum Pursh syn. Pseudoroegneria spicata (Pursh) A.Love), Idaho fescue (Festuca idahoensis Elmer), and squirreltail. The $2,000 \mathrm{~m}^{2}$ site was cleared of western juniper during the fall of 1982 and allowed to revegetate naturally (Vaitkus and Eddleman 1991). Squirreltail cover on the site in 1995 was approximately $1.2 \%$ (L. E. Eddleman unpublished data). Soils on the study site have been classified as relativley shallow (330 $\mathrm{mm}$ ), clayey-skelatal, frigid Pachic Argixerolls (Vaitkus and Eddleman 1991). 
Seeds were collected from squirreltail individuals throughout the plot beginning approximately 2 weeks following anthesis and ending when a majority of seed heads were disarticulating. In 1995, seeds were collected at 1-week intervals from 21 June to 26 July. In 1996, seeds were collected at approximately 10-day intervals from 21 June to 23 July. Phenology of squirreltail plants was recorded at times of collection.

Inflorescences were placed in paper bags and stored at room temperature. Seeds were cleaned using a small mechanical thresher, which also removed the awn. Light, unfilled seeds were seperated mauually by placing on a light table.

\section{Experimental procedure}

Seeds were germinated in an environmental chamber at $20^{\circ} \mathrm{C}\left(+/-3^{\circ} \mathrm{C}\right)$ in darkness (Young and Evans 1977). Four replications of 25 seeds each were used for each collection. Seeds were imbibed with distilled water on cellulose pads in plastic petri dishes. Germination counts were made for 21 days. A seed was considered germinated when either radicle or plumule had grown at least $2 \mathrm{~mm}$. Seeds collected in 1995 were germinated during May 1996 and seeds collected in 1996 were germinated in November 1996. The germination count was made daily from the third day of the trial for the May 1996 test, and from the first day of the Nov. 1996 test. In addition to germination counts, 5 replicates of 25 air-dried seeds were weighed for seed collected in both years.

Total germination percentage, days to $50 \%$ germination, and seed weight were used to assess differences between collection dates. An analysis of variance was used to assess germination response. When a significant $\mathrm{F}$ test $(\mathrm{P}=0.05)$ was found in the analysis of variance, a protected Least Significant Difference mean comparison test was applied to assess differences among collections within a year (Steel and Torrie 1980). Only significant differences $(\mathrm{P}=0.05)$ are reported in the text.

\section{Results and Discussion}

Squirreltail required 4 to 5 weeks to reach disarticulation after anthesis (Table 1). When awns were a reddish color and seeds progressing into a hard dough stage, about 14 days remained until active disarticulation.

Early seed harvest before the hard dough stage provided germinable seeds while at the same time avoided disarticulation of the seed head. Germinable seeds were present in all collections of 1995

Table 1. Phenological description of Squirreltail at the time of collection.

\begin{tabular}{|c|c|}
\hline Date & Description \\
\hline 21 June & $\begin{array}{l}\text { Majority of flowering culms in mid to late anthesis, approximately } 15 \% \text { just out of } \\
\text { the boot stage. }\end{array}$ \\
\hline 28 June & $\begin{array}{l}\text { Approximately } 10 \% \text { of inflorescences approaching maturity, majority of inflores- } \\
\text { cences in late flowering or florets in early soft dough state of seed development. }\end{array}$ \\
\hline 5 July & Majority of florets in early to mid-dough stage of development. \\
\hline 12 July & $\begin{array}{l}\text { Majority of florets in late dough state, awns are turning red, }<5 \% \text { of inflore- } \\
\text { cences are mature. Plants beginning to turn a straw/red color. }\end{array}$ \\
\hline 19 July & $\begin{array}{l}\text { Approximately } 50 \% \text { of all inflorescences are mature as evidenced by straw color } \\
\text { and divergent awns. The other inflorescences still with red awns and embryo is in } \\
\text { hard dough stage. }\end{array}$ \\
\hline 26 July & $\begin{array}{l}>75 \% \text { of inflorescences are mature and disarticulating. }<25 \% \text { of inflorescences } \\
\text { are late maturing and awns still red and straight. }\end{array}$ \\
\hline 21 June & Inflorescenses in late boot stage to early anthesis. \\
\hline 1 July & Majority of inflorescenses exhibit red awns, seeds in mid-dough stage. \\
\hline 11 July & Majority of inflorescences with straight, red awns, seeds hard. \\
\hline 23 July & $\begin{array}{l}>90 \% \text { of inflorescences mature and beginning to disarticulate. Awns divergent, } \\
\text { approximately } 10 \% \text { of inflorescences with straight red awns. }\end{array}$ \\
\hline
\end{tabular}

seeds, and in all collections of 1996 seeds except for 21 June (early anthesis stage) (Table 2). In both years total germination percentages increased with seed maturation, with greater than $80 \%$ germination after the mid-to late-dough stages. Germination percentages were not different among the 12 July, 19 July, and 26 July dates in 1995. In 1996, no differences were found between the 11 July and 23 July collections.

Speed of germination was similar among the collections in 1995 except for slower germinating seeds on 28 June (Table 2). For 1996, fastest germination was for the later harvested seeds. In the

Table 2. Mean percent germination and days required for $50 \%$ germination, and seed weight (gram per 100 seeds) of Squirreltail seeds collected in 1995 and 1996.

\begin{tabular}{lccc}
\hline $\begin{array}{l}\text { Collection } \\
\text { date }\end{array}$ & $\begin{array}{c}\text { Germination } \\
\text { percentage }\end{array}$ & $\begin{array}{c}\text { Days to 50\% } \\
\text { germination }\end{array}$ & $\begin{array}{c}\text { Seed } \\
\text { weight }\end{array}$ \\
\hline 1995 & $\begin{array}{c}(\%) \\
\text { 21 June }\end{array}$ (Days) & $(\mathrm{g} / 100$ seeds $)$ \\
28 June & $8 \mathrm{c}$ & $5.5 \mathrm{ab}$ & $0.12 \mathrm{c}$ \\
5 July & $80 \mathrm{~b}$ & $6.8 \mathrm{a}$ & $0.16 \mathrm{c}$ \\
12 July & $99 \mathrm{a}$ & $5.5 \mathrm{ab}$ & $0.24 \mathrm{~b}$ \\
19 July & $94 \mathrm{a}$ & $5.0 \mathrm{~b}$ & $0.24 \mathrm{~b}$ \\
26 July & $100 \mathrm{a}$ & $4.0 \mathrm{~b}$ & $0.36 \mathrm{a}$ \\
S.E.D. & 1.72 & $4.0 \mathrm{~b}$ & $0.40 \mathrm{a}$ \\
1996 & & 0.6 & 0.04 \\
21 June & $0 \mathrm{a}$ & - & $0.09 \mathrm{c}$ \\
1 July & $41 \mathrm{~b}$ & $4.3 \mathrm{a}$ & $0.12 \mathrm{~d}$ \\
11 July & $81 \mathrm{c}$ & $2.8 \mathrm{~b}$ & $0.18 \mathrm{~b}$ \\
23 July & $99 \mathrm{c}$ & $2.0 \mathrm{a}$ & $0.32 \mathrm{a}$ \\
S.E.D. & 2.2 & 0.3 & 0.04 \\
\hline
\end{tabular}

${ }^{\mathrm{M}}$ Means followed by a similar letter are not significantly different within a year $(\mathrm{P} \leq 0.05)$.

${ }^{2}$ Standard error of the difference. event that a seed lot exhibits slow germination rates, a seedling may be put at risk on weed infested sites. Depletion of soil moisture by competing species usually conveys a late-emerging seedling to dessication and death (Harris 1967, Pyke 1990). In squirreltail, later harvest resulted in greater total germination and for 1996, more rapid germination. Trying to maximize these attributes in a seed lot is important because they may impart a greater chance of seeding success in competitive environments.

Reasons for lower germination amounts in earlier collected squirreltail seeds may be related to seed weight and maturation of 
the seed head at the time of collection. In both 1995 and 1996, weight of seeds became significantly heavier for seeds collected later in the growing season (Table 2). Heavier seeds within a seed lot have been shown to exhibit higher germination amounts and better seedling emergence characteristics than lighter seeds (Aiken and Springer 1995, Limbach and Call 1996, Hou and Romo 1998). Seeds collected later in the process of seed head maturation also exhibit greater seed germination amounts (Phaneendranath et al. 1978). Attention to maximizing seed weight and harvesting seed heads close to maturity are important considerations when trying to optimize revegetation success.

\section{Management Considerations}

Squirreltail appears to hold desirable properites to aid in restortion of degraded sagebrush grasslands in the Intermountain West. When seeds of squirreltail are collected, it is recommended they be made as close to inflorescence disarticulation as possible. When approximately $50 \%$ of seed heads have divergent awns and the other half have straight awns but a reddish color, seeds will exhibit strong germination properties. This generally corresponds to a week before seed head disarticulation and may make harvesting with mechanical devices easier. Control of competing vegetation, although beneficial for all seedings, would be critical for earlier harvested seed.

\section{Literature Cited}

Aiken, G. E. and T.L. Springer. 1995. Seed size distribution, germination, and emergence of 6 switchgrass cultivars. J. Range Manage. 48:455-458.

Harris, G. A. 1967. Some competitive relationships between Agropyron spicatum and Bromus tectorum. Ecol. Monogr. 37:89-111.

Hironaka, M. and B.W. Sindelar. 1973. Reproductive success of squirreltail in medusahead infested ranges. J. Range Manage. 26:219-221.

Hironaka, M. and B.W. Sindelar. 1975. Growth characteristics of squirreltail in competition with medusahead. J. Range Manage. 29:283-285.

Hironaka, M. and E. W. Tisdale. 1963. Secondary succession in annual vegetation in southern Idaho. Ecol. 44:810-812.

Hou , J. and J. T. Romo. 1998. Seed weight and germination time affect growth of 2 shrubs. J. Range Manage. 51:699-703.

Jones, T. A. 1998. Viewpoint: The present status and future prospects of squirreltail research. J. Range Manage. 51:326-331.

Limbach, W.E. and C.A.Call. 1996. Germination response of Russian wildrye to variations in seed mass at fluctuating temperatures. J. Range Manage. 49:346-349.

Mack, R. N. and D. A. Pyke. 1984. The demography of Bromus tectorum: The role of microclimate, grazing and disease. J. Ecol. 72:731-748.

Phaneendranath, B. R., R. W. Duell, and C. R. Funk. 1978. Dormancy of Kentucky bluegrass seed in relation to the color of spikelets and panicle branches at harvest. Crop Sci. 18:683-684.

Pyke, D. A. 1990. Comparative demography of co-occurring introduced and native tussock grasses: Persistence and potential expansion. Oecologia 82:537-543.
Steel , R.G.D. and J.H. Torrie. 1980 . Principles and procedure of statistics. McGraw Hill Book Company. Inc., New York., N. Y.

Vaitkus, M. R. and L. E. Eddleman. 1991. Tree size and understory phytomass production in a western juniper woodland. Great Basin Natur. 51:236-243.

Young, J. A. and R. A. Evans. 1977. Squirreltail seed germination. J. Range Manage. 30:33-36. 